\title{
Cyprideis Torosa (Ostracoda, Crustacea): Occurrence Patterns, Carapace Type And Its Relationship To Physicochemical Variables In Kocaçay Delta (Turkey)
}

\author{
Okan Külköylüoğlu ( okankul@gmail.com ) \\ Bolu Abant İzzet Baysal University https://orcid.org/0000-0003-4712-5612 \\ Mehmet Yavuzatmaca \\ Bolu Abant İzzet Baysal University https://orcid.org/0000-0002-0398-6763 \\ Enis Akay \\ Bursa Uludağ University https://orcid.org/0000-0001-5363-3205 \\ Nurhayat Dalkıran \\ Bursa Uludağ University https://orcid.org/0000-0002-1222-8809
}

\section{Research Article}

Keywords: noding, seasonality, ecological tolerances, fossil and recent distribution.

Posted Date: February 14th, 2022

DOI: https://doi.org/10.21203/rs.3.rs-1303861/v1

License: (c) (i) This work is licensed under a Creative Commons Attribution 4.0 International License. Read Full License 


\section{Abstract}

To understand spatial and temporal continuing occurrence patterns and relationships of Cyprideis torosa to several physicochemical variables, monthly samples from seven stations were collected from Kocaçay Delta (Bursa, Turkey) between 2018 and 2019. Four (C. torosa, Koencypris ornata, Candona lindneri, Candona meerfeldiana) of 14 ostracod taxa are new records for the ostracod fauna of Bursa province where total numbers of recent species increased to 33. Cyprideis torosa was the only dominant species found in almost all samples throughout the sampling. Based on carapace type of the species, three groups can be divided as i) Type-1 (smooth carapaces), ii) Type-2 (noded carapaces), and iii) Type-3 (both carapaces noded on one valve and smooth on the other). Different occurrence patterns of the species with overlapping ecological ranges were observed among the stations. Except for station 1, all the types were encountered from other stations. Beginning from December 2018, nearly all populations had mostly Type-1 individuals until the end of March. During April-May, individuals with Types-2 and 3 appear to increase until the end of October while individuals in Type-2 group were solely found from three stations (2, 3 and 5) in March and May 2018. There was a significant difference in salinity, magnesium, and calcium values among the stations $(\mathrm{P}<0.05)$ but only total nitrogen, temperature and calcium showed a medium correlation to carapace type. In all cases, populations with noded individuals were found in narrower ecological ranges for those variables than other populations with smooth individuals.

\section{Introduction}

The genus Cyprideis (Cytherideidae) includes about 31 species (Meisch et al 2019). Of which, Cyprideis torosa with wider geographic distribution than other species (Karanovic 2012) has been found mostly in highly saline (eurysaline), brackish and/or marine habitats (so called "halophilic species" (Bronstein 1947)) and less frequently in freshwater habitats (Hartmann 1964). This is because the species shows broad tolerance ranges to salinity (Aladin 1993) and temperature values in several different aquatic ecosystems such as springs (Gülen 1985) and small water bodies and irrigation canals (Akdemir and Külköylüoğlu 2021). Also, live individuals of C. torosa have been recorded from streams (Külköylüoğlu et al 2020) and a lake (Lake Bafa) in Turkey (Akdemir et al 2020) where electrical conductivity values were below $400 \mu \mathrm{S} / \mathrm{cm}$, referring to freshwater conditions. Cyprideis torosa was also reported from several other inland water types (e.g., springs, ditches, pit, ponds and brooks) in Germany where electrical conductivities ranged from 750 to $77400 \mu \mathrm{S} / \mathrm{cm}$ (Scharf et al 2017). Wouters (2017) clearly pointed out that species can be found from coastal zones of fresh, brackish, and marine habitats with high salinity values where the species was reported from 0.2 to $80 \%$ of salinity ranges in waters (e.g., see Bardawil inner lagoon) (Rosenfeld and Vesper 1977). Moreover, C. torosa can be active in waters with broad temperature ranges from 1.0 खC (Ustaoğlu et al 2012 ) to ca. 34.5 \C (Bodergat et al 2014). Dykan (2016) underlined that the species is highly abundant in density in a range of 0-25 $₫ \mathrm{C}$ temperature between 3 and $5 \mathrm{~m}$ of depth at Northern Black Sea coasts. Additionally, laboratory experiments (see details in Jahn et al 1996) also showed that at least $50 \%$ of $C$. torosa tolerated hypoxic (reduced oxygen of $70 \%$ air saturation) conditions along with very high ( $1 \mathrm{mM}$ and $1.8 \mathrm{mM}$ ) hydrogen sulfide concentrations for three weeks. Hence, it is clearly seen that $C$. torosa is one of the most tolerant species to several different environmental variables and this can explain its wide geographic distribution ranging from fresh to euryhaline coastal waters.

Cyprideis torosa is a polymorphic species with different populations including individuals with noded or unnoded (smooth) carapace. Historically speaking, these two types were considered two different species and/or forms due to presence (forma torosa) or absence (forma littoralis) of nodes on the carapace (see Sars 1928; Klie 1938; Elofson 1941). However, it was later pointed out that such difference was probably related to changes in environmental conditions (e.g., salinity) (Van Morkhoven 1962; Keyser 2005; Frenzel et al 2012; Frogley and Whittaker 2016; Berndt et al 2019). Moreover, finding both forms from the same sites has already been reported in recent (e.g., Triebel 1941; Külköylüoğlu et al 1993, 1995; Scharf et al 2017; this study) and fossil forms (Nazik et al 2008; Witt 2010; Tuncer, pers. comm.), supporting that the two forms belonging to a single species as Cyprideis torosa (Meisch 2000). Besides the presence of some morphological characters (e.g., length of carapace, posteroventral spine on the right valve, shape of hemipenis and clasping organs, length of terminal claw and medial seta of the fourth segment of the first antenna) (Van Harten 1975; Wouters 2017), presence/absence of nodes has been commonly used for species identification both in fossil and live (recent) samples. There are plenty of studies (e.g., see Sandberg 1964; Kilenyi 1972; Vesper 1972a, b; Heip, 1976a, b; Keyser and Aladin 2004; Keyser 2005; Wouters 2017) on the occurrence of the nodes. It was earlier considered that node formation might be a genetic response. However, as shown by the studies of Keyser and Aladin (2004) and Keyser (2005), appearance of the nodes corresponds to decreasing of salinity levels during the molting stages due to osmoregulation. Therefore, nodes are most likely environmentally induced. This implies that individuals with nodes can be more likely found in oligohaline habitats (< $5 \%$ of salinity). Indeed, a few well-known long-term studies based on monthly samplings (Vesper 1972a, b; Heip 1976a, b) and studies with seasonal samplings (e.g., Külköylüoğlu et al $1993,1995)$ provided supportive evidence for the previous works. These studies underlined that noding may be related to monthly occurrence of the species because of the monthly or seasonal influence of air temperature on the aquatic ecosystems.

As stated above, C. torosa has a wide geographic distribution (Sandberg 1964). According to Wouters (2002, 2003,2017 and references in there), the species has been known from Africa, Asia, Europe and above the Arctic Circle (see Schornikov 2011) but its occurrence may be questionable from Australia (De Deckker and Lord 2017). King and Kornicker (1970) and Heip (1976a) had already reported the species from several sites in North America, but Wouters (2017) indicated that the species reported in there were synonyms and $C$. torosa was not known from the Americas. Besides, Sandberg (1964) in his detailed work on the species provided a list of Cyprideis species from Americas but not C. torosa. However, Sandberg (1964, see p. 93) did not collect specimens from North America but used several materials gained from A. G. Davis Collection (British Natural History Museum) and juvenile valves from Kijkduin (Holland). In contrast, recently, Pint and Frenzel (2017) reported the species from Nevada (North America) and Chile (South America) while it was also reported from Texas (Külköylüoğlu et al 2021a). Thus, considering all the studies above (and several others cited in there) and doubts about its occurrence in Australia suggest that the species almost exhibit cosmopolitan distribution in all continents, except the poles. 
Although quantity of studies on the species ecology, biology and distribution exists in the literature, there is no extensive and comparative study on its monthly occurrence patterns along with carapace type and distribution of fossil and recent populations of the species in Turkey. This is, however, important issue that presence of the species with or without nodes can aid to (i) understand salinity and temperature changes and/or fluctuations in aquatic bodies, (ii) estimate and possibly reconstruct the past aquatic conditions sought in paleontological studies, (iii) compare levels of changes between the past and present water quality measurements, and (iv) create proxy models and scenarios for future aquatic conditions which can elaborate our understanding about possible impact of climatic changes. The aims of the present study focus on three points to (1) accomplish first monthly sampling of $C$. torosa along with its correlation to some environmental variables (e.g., salinity and temperature) in the Kocaçay Delta, (2) search relationship between occurrence patterns and carapace type, and (3) compare species distribution both in fossil and recent populations in Turkey.

\section{Materials And Methods}

Sampling area (Figure 1) is located in Kocaçay Delta Floodplain Forest (ca. 42.000 hectares of surface area) which is known to be one of the most important floodplains in Turkey. Kocaçay stream (aka Susurluk Stream) reaches to the Marmara Sea after it receives water from several different aquatic bodies such as Mustafakemalpaşa Stream and Lake Manyas in the east of Karacabey District (Bursa province). It develops a large floodplain delta including two lakes (Arapçiftliği and Dalyan lakes, in the East and West of the stream, respectively), swamps, sand dunes, and floodplain (longoz) forest (Keçeli and Ursavaş 2019) where it emerges to the Marmara Sea.

\section{Figure 1 here...}

Monthly samples were taken from seven stations (Figure 1) from the Kocaçay Delta (Bursa, Turkey) between 30 March 2018 and 04 April 2019 . Water samples for chemical analyses were collected from each station in plastic bottles (100 ml). Chemical analyses were done after APHA (1998) methods. Lovibond Senso multiprobe was used to measure water temperature $(\mathbb{C})$, $\mathrm{pH}$, dissolved oxygen $(\mathrm{mg} / \mathrm{L})$ and electrical conductivity $(\mathrm{mS} / \mathrm{cm})$ in situ. Ostracod samples taken from the littoral zones (stations $1,2,5,6,7$ ) were collected from the shores (ca. $1 \mathrm{~m}^{2}$ area with a maximum of $1 \mathrm{~m}$ depth) with a hand net ( $0.5 \mathrm{~mm}$ mesh size) and fixed with $70 \%$ alcohol in $200 \mathrm{ml}$ plastic bottles. Other samples taken from the pelagic sites (stations 3 and 4 ) of the lakes were collected with Ekman bottom grab (152x152x152 mm in size) (ENVCO). These samples were filtered through Retsch brand stainless sieve and separated from the sediment as much as possible. Then after, samples were fixed in plastic bottles with $70 \%$ alcohol in situ. In the laboratory, all individual samples were separately washed under the tap water through three standard seized sieves $(0.5,1.0,2.0 \mathrm{~mm}$ of mesh size) and fixed with $70 \%$ ethanol for future studies. We used a stereomicroscope (Olympus SZ-STLA) for sorting specimens from the sediment and dissecting them in lactophenol solution. Individual specimens were dissected with fine needles (no: 000) and covered with cover slide while related information (gender, dimensions, sampling date, site name etc.) was noted on each of them. Whenever possible, taxonomic identification at the species level was done under a light microscope (Olympus BX-51). Taxon is left as "sp." if lacking undamaged and adult individuals. Carapace and/or valves of dissected species were kept on micropaleontological slides. We basically followed the taxonomic keys of Meisch (2000) during identification. All samples were placed in the Limnology Laboratory, Department of Biology, Bolu Abant Izzet Baysal University, Bolu, Turkey. Comparison of the measured values among the stations was done with the non-parametric t-test with equal variances (significant if $\mathrm{P}<0.05$ ). In order to comprehend possible relationships among carapace type (Type-1 (smooth carapaces), Type-2 (noded carapaces), and Type-3 (both carapaces noded on one valve and smooth on the other), abundance values (numbers of live adult individuals) and measured physicochemical variables, we used Spearman correlation analysis and ternary plots obtained from the PAST 4.03 program (Hammer et al 2001).

\section{Results}

Total of 10 recent and four subfossil ostracod taxa (Candona angulata, C. lindneri, C. meerfeldina, Candona sp., Cypria sp., Cyprideis torosa, Cypridopsis sp., Eucypris sp., Heterocypris salina, llyocypris sp., Koencypris ornata, Limnocythere sp., Plesiocypridopsis sp. and Potamocypris sp.) were reported from the present study. Four of the reported taxa ( $C$. torosa, $K$. ornata, $C$. lindneri, and $C$. meerfeldiana) increased the numbers of documented recent species up to 33 in the Bursa province. Cyprideis torosa, most frequently occurring dominant species, was observed in almost all samples throughout the sampling period (but see a few exceptions) (Figure 1, Table 1). Based on carapace type of the species, three groups can be separated as i) Type-1 with smooth carapaces, ii) Type-2 with noded carapaces, and iii) Type-3 with carapaces noded on one side and smooth on the other. Different occurrence patterns were observed among the stations (Table 1). While one live female and three subfossils (carapace and valves) of $C$. torosa with all smooth carapaces were found at station 1, populations with all three types of carapaces were randomly encountered from other stations. Live individuals were found in wide ranges of salinity $(0.21-28.89 \mathrm{mS} / \mathrm{cm})$ and water temperature $(6.03-34 \varangle \mathrm{C})$, corresponding to the known ranges (Table 2). There was a significant difference in the values of salinity, magnesium $(\mathrm{Mg})$, and calcium $(\mathrm{Ca})$ among some stations $(\mathrm{P}<0.05)$ while no significant difference was found for other variables. These differences were especially apparent between two stations (1st and 6th) located furthest in distance to the Marmara Sea. Spearman correlation analyses exhibited medium but not significant correlations for water temperature, Ca and total nitrogen with carapace type while none of the variables examined in here revealed a significant correlation with the abundance values (Table 3 ). It seems that carapace type may be related to seasonal changes; for instance, beginning from November until April, almost all populations had mostly smooth carapaces. During April-May, individuals with Types- 2 and 3 carapaces appear to increase until end of October. In all cases, populations with noded individuals were found in narrower ranges for those variables than other populations with smooth and/or smooth and noded individuals while the first rank was changed between the smooth and smooth-noded populations at different sites and sampling time (Table 1). Comparison of the fossil and recent populations showed that distribution and reports of fossil forms was wider than recent $C$. torosa populations in Turkey (Figure 2). Overall, electrical conductivity (referring to salinity) seems to be more effective on the species occurrence and/or abundance more than $\mathrm{Mg}$ and Ca alone (Figure 3 ). Results suggest that occurrence of nodes on the carapace can be affected by both temporal and spatial conditions. 
Table 1

Monthly distribution of Cyprideis torosa among seven stations (St No). Abbreviations: $m$ (adult male), $f$ (adult female), S (smooth), N (noded), NS (noded + smooth) carapaces. Recent (live individuals), Subfossil (surface sediment samples) (adult carapace or valves), Rec Juv (live juveniles) and Fos Juv (subfossil

juveniles/only carapace or valves).

\begin{tabular}{|c|c|c|c|c|c|c|}
\hline Date & St No & Carapace & Recent & Subfossil & Rec Juv & Fos Juv \\
\hline 30.03.2018 & 1 & & & & & \\
\hline 30.03.2018 & 2 & $S$ & 1 & & & \\
\hline 30.03.2018 & 3 & $S$ & $4 f$ & & & \\
\hline 30.03.2018 & 4 & $S$ & $1 \mathrm{~m} 1 \mathrm{f}$ & 8 & & \\
\hline 30.03.2018 & 5 & $\mathrm{~N}$ & $1 f$ & & & \\
\hline 30.03.2018 & 6 & & & & & \\
\hline 30.03.2018 & 7 & & & & & \\
\hline 4.05.2018 & 1 & & & & & \\
\hline 4.05.2018 & 2 & $\mathrm{~N}$ & $2 m 16 f$ & & & \\
\hline 4.05.2018 & 3 & $\mathrm{~N}$ & $6 m 1 f$ & 1 & & \\
\hline 4.05.2018 & 4 & NS & $>100$ & $>100$ & & \\
\hline 4.05.2018 & 5 & NS & $3 m 9 f$ & $>100$ & & \\
\hline 4.05.2018 & 6 & NS & & 2 & & \\
\hline 4.05.2018 & 7 & NS & $7 m 18 f$ & 1 & & \\
\hline 28.05.2018 & 1 & $S$ & & & & \\
\hline 28.05.2018 & 2 & $S$ & & 2 & & \\
\hline 28.05.2018 & 3 & $S$ & $1 \mathrm{~m}$ & & & \\
\hline 28.05.2018 & 4 & $S$ & $1 \mathrm{~m} 3 \mathrm{f}$ & & 2 & \\
\hline 28.05.2018 & 5 & & & & & \\
\hline 28.05.2018 & 6 & & & & & \\
\hline 28.05.2018 & 7 & $S$ & & 1 & & \\
\hline 2.08.2018 & 1 & & & & & \\
\hline 2.08.2018 & 2 & $S$ & 2 & & & 2 \\
\hline 2.08.2018 & 3 & $S$ & $1 \mathrm{~m} 4 \mathrm{f}$ & & 1 & \\
\hline 2.08.2018 & 4 & $S$ & $3 f$ & 1 & & \\
\hline 2.08.2018 & 5 & NS & $>100$ & $>100$ & $>100$ & $>100$ \\
\hline 2.08.2018 & 6 & NS & & 1 & 1 & \\
\hline 2.08.2018 & 7 & NS & $>100$ & $>100$ & $>100$ & $>100$ \\
\hline 5.09 .2018 & 1 & & & & & \\
\hline 5.09 .2018 & 2 & NS & $10 \mathrm{~m} 35 \mathrm{f}$ & 1 & 1 & \\
\hline 5.09 .2018 & 3 & NS & $8 \mathrm{~m} 11 \mathrm{f}$ & 1 & 1 & \\
\hline 5.09 .2018 & 4 & $S$ & $3 f$ & 20 & 1 & \\
\hline 5.09 .2018 & 5 & NS & $>100$ & $>100$ & $>100$ & $>100$ \\
\hline 5.09.2018 & 6 & NS & $1 f$ & 1 & 2 & \\
\hline 5.09.2018 & 7 & NS & $>100$ & $>100$ & $>100$ & $>100$ \\
\hline 29.09.2018 & 1 & & & & & \\
\hline 29.09.2018 & 2 & NS & $8 m 28 f$ & 1 & 5 & \\
\hline 29.09 .2018 & 3 & NS & $3 m 2 f$ & 1 & 4 & \\
\hline
\end{tabular}




\begin{tabular}{|c|c|c|c|c|c|c|}
\hline Date & St No & Carapace & Recent & Subfossil & Rec Juv & Fos Juv \\
\hline 29.09.2018 & 4 & NS & $8 m 49 f$ & $>100$ & $>100$ & \\
\hline 29.09 .2018 & 5 & NS & $>100$ & $>100$ & $>100$ & $>100$ \\
\hline 29.09 .2018 & 6 & NS & $1 \mathrm{~m} 5 \mathrm{f}$ & 2 & & \\
\hline 29.09 .2018 & 7 & NS & $>100$ & $>100$ & $>100$ & $>100$ \\
\hline 24.10.2018 & 1 & S & $1 f$ & 2 & & \\
\hline 24.10.2018 & 2 & $S$ & $7 m 9 f$ & 1 & 1 & \\
\hline 24.10.2018 & 3 & $S$ & $17 \mathrm{~m} 53 \mathrm{f}$ & $>100$ & $>100$ & \\
\hline 24.10.2018 & 4 & NS & $2 m 6 f$ & $>100$ & $>100$ & \\
\hline 24.10.2018 & 5 & NS & $31 \mathrm{~m} 40 \mathrm{f}$ & $>100$ & & $>100$ \\
\hline 24.10.2018 & 6 & $S$ & & 1 & & \\
\hline 24.10.2018 & 7 & $S$ & $27 m 42 f$ & $>100$ & $>100$ & $>100$ \\
\hline 20.12.2018 & 1 & $S$ & & 1 & & \\
\hline 20.12 .2018 & 2 & & & & & \\
\hline 20.12.2018 & 3 & $S$ & $2 m 3 f$ & 5 & & \\
\hline 20.12 .2018 & 4 & $S$ & $2 m 8 f$ & $>100$ & $>100$ & \\
\hline 20.12.2018 & 5 & $S$ & & 2 & & \\
\hline 20.12.2018 & 6 & $S$ & & 1 & & \\
\hline 20.12 .2018 & 7 & & & & & \\
\hline 17.01 .2019 & 1 & & & & & \\
\hline 17.01 .2019 & 2 & $S$ & & 3 & & \\
\hline 17.01 .2019 & 3 & $S$ & $2 m 38 f$ & 2 & & \\
\hline 17.01.2019 & 4 & $S$ & $7 m 4 f$ & $>100$ & $>100$ & \\
\hline 17.01.2019 & 5 & $S$ & $4 m 3 f$ & 9 & & \\
\hline 17.01.2019 & 6 & $S$ & & 1 & & \\
\hline 17.01.2019 & 7 & & & & & \\
\hline 20.02.2019 & 1 & & & & & \\
\hline 20.02.2019 & 2 & $S$ & $5 m 5 f$ & 1 & 1 & \\
\hline 21.02 .2019 & 3 & NS & $10 \mathrm{~m} 40 \mathrm{f}$ & 1 & $>100$ & \\
\hline 22.02.2019 & 4 & $S$ & $>100$ & $>100$ & & \\
\hline 23.02.2019 & 5 & $S$ & $2 f$ & 2 & & \\
\hline 24.02.2019 & 6 & & & & & \\
\hline 25.02.2019 & 7 & $S$ & & 11 & & \\
\hline 4.04.2019 & 1 & & & & & \\
\hline 4.04.2019 & 2 & & & & & \\
\hline 4.04.2019 & 3 & $S$ & $2 m 9 f$ & 1 & & \\
\hline 4.04 .2019 & 4 & $S$ & $2 \mathrm{~m} 1 \mathrm{f}$ & 2 & & \\
\hline 4.04.2019 & 5 & $\mathrm{~N}$ & & 1 & & \\
\hline 4.04.2019 & 6 & & & & & \\
\hline 4.04.2019 & 7 & $S$ & $4 \mathrm{~m} 2 \mathrm{f}$ & 2 & & \\
\hline
\end{tabular}


Table 2

Mean, maximum (MAX) and minimum (MIN) values $(n=77)$ of 13 variables for Cyprideis torosa with noded, nodes + smooth, and smooth carapaces Abbreviations: DO (dissolved oxygen, $\mathrm{mg} / \mathrm{L}), \mathrm{EC}$ (electrical conductivity, $\mathrm{mS} / \mathrm{cm})$, water temperature $\left(\mathrm{T}^{\circ} \mathrm{C}\right)$, salinity $($ Sal, $\mathrm{ppt}), \mathrm{phosphate}\left(\mathrm{PO} \mathrm{H}^{-} \mathrm{P}\right)$, total phosphate (TP), nitrite $\left(\mathrm{NO}_{2}-\mathrm{N}\right)$, nitrate $\left(\mathrm{NO}_{3}-\mathrm{N}\right)$, total nitrogen $(\mathrm{TN})$, and suspended solid matters (SSM) (all units are in mg/L unless otherwise indicated).

\begin{tabular}{|c|c|c|c|c|c|c|c|c|c|c|c|c|c|c|}
\hline & DO & $\mathrm{pH}$ & EC & T囚C & Sal & $\mathrm{Mg}$ & $\mathrm{Ca}$ & $\begin{array}{l}\mathrm{PO}_{4}^{-} \\
\mathrm{P}\end{array}$ & TP & $\mathrm{NO}_{2}-\mathrm{N}$ & $\begin{array}{l}\mathrm{NO}_{3}- \\
\mathrm{N}\end{array}$ & TN & SSM & $\begin{array}{l}\text { Cyprideis } \\
\text { torosa }\end{array}$ \\
\hline MEAN & 7.13 & 8.18 & 12.82 & 17.08 & 7.44 & 694.33 & 254.59 & 0.055 & 0.138 & 0.0140 & 0.167 & 3.531 & 35.35 & Noded \\
\hline MAX & 9.80 & 8.51 & 18.06 & 19.60 & 10.67 & 875.52 & 384.77 & 0.171 & 0.209 & 0.0490 & 0.403 & 4.827 & 46.70 & \\
\hline MIN & 5.10 & 7.84 & 3.89 & 15.18 & 2.05 & 228.69 & 24.05 & 0.010 & 0.077 & 0.0010 & 0.073 & 2.197 & 22.30 & \\
\hline MEAN & 7.06 & 8.42 & 16.47 & 24.18 & 9.92 & 937.83 & 342.58 & 0.102 & 0.326 & 0.0260 & 0.229 & 5.425 & 70.33 & Noded+Smooth \\
\hline MAX & 11.90 & 8.79 & 44.70 & 34.00 & 28.89 & 3112.96 & 801.60 & 0.369 & 1.253 & 0.2010 & 1.099 & 16.370 & 175.30 & \\
\hline MIN & 3.40 & 7.93 & 0.64 & 13.20 & 0.31 & 82.69 & 68.14 & 0.006 & 0.054 & 0.0001 & 0.027 & 1.595 & 13.40 & \\
\hline MEAN & 7.45 & 8.25 & 10.41 & 15.76 & 6.26 & 555.23 & 197.85 & 0.071 & 0.203 & 0.0090 & 0.263 & 3.220 & 54.67 & Smooth \\
\hline MAX & 10.80 & 8.83 & 28.30 & 30.17 & 17.42 & 2315.24 & 673.34 & 0.277 & 0.587 & 0.1350 & 1.738 & 5.893 & 215.30 & \\
\hline MIN & 1.90 & 7.37 & 0.442 & 6.03 & 0.21 & 2.43 & 12.02 & 0.003 & 0.050 & 0.0006 & 0.038 & 1.925 & 11.20 & \\
\hline
\end{tabular}

Table 3

Results of Spearman correlation analyses between the numbers of living adult $C$. torosa (Numlnd) and carapace type (Car. Type) with 12

variables. Bold numbers show medium but not significant correlations for T囚C Ca and TN. See the text and Table 2 for the units. "Numlnd" represents the calculated values after abundances.

\begin{tabular}{|c|c|c|}
\hline Variable & Numlnd & Car. Type \\
\hline DO & -0.045 & -0.150 \\
\hline $\mathrm{pH}$ & 0.190 & 0.158 \\
\hline $\mathrm{T} \otimes \mathrm{C}$ & 0.119 & 0.389 \\
\hline Salinity & 0.237 & 0.234 \\
\hline $\mathrm{Mg}$ & 0.235 & 0.291 \\
\hline $\mathrm{Ca}$ & 0.223 & 0.342 \\
\hline $\mathrm{PO}_{4}-\mathrm{P}$ & 0.092 & 0.067 \\
\hline TP & 0.147 & 0.189 \\
\hline $\mathrm{NO}_{2}-\mathrm{N}$ & 0.135 & 0.033 \\
\hline $\mathrm{NO}_{3}-\mathrm{N}$ & 0.061 & -0.102 \\
\hline $\mathrm{TN}$ & 0.258 & 0.429 \\
\hline SSM & 0.249 & 0.075 \\
\hline
\end{tabular}

Figure 2 here...

Figure 3 here...

Table 1 here...

Table 2 here...

Discussion And Conclusion Co-occurrence and salinity 
With the additional reports in here, numbers of non-marine ostracods in Bursa province increased up to 33 species. This number is more than many other provinces in similar size in Turkey (Külköylüoğlu et al 2021b), but it is still considered underestimation since previous reports are based on random and/or mostly one-time sampling effort that there is no extensive study on the ostracod fauna of the province. Meanwhile, looking at the abundance of individual species, it is clearly seen that $C$. torosa is the only dominant species encountered along with nine other recent taxa (Table 1$)$. Of which, four candonids $(C$. angulata, C. meerfeldiana, C. cf. lindneri, Candona sp.) were the most accompanying taxa with C. torosa followed by others (Cypria sp., Heterocypris salina, Eucypris sp., Potamocypris sp., Plesiocypridopsis sp.). It is already known that some of these taxa can be found from fresh to saline habitats together with C. torosa (Meisch 2000; Scharf et al 2017; Pint and Frenzel 2017; McCormack et al 2019). However, comparison of the abundance values amid taxa portrayed the fact that $C$. torosa was generally over numbered (>98\%) during our study. Plotnikov et al. (2021) reported that $C$. torosa was the most common species with long-term tolerance to salinity increase in Aral Sea. These authors found different occurrence frequencies of the species between Large Aral (salinity range 8-13 ppt) and Small Aral (salinity range 0-3 ppt). The species was the last survivor during salinity increase in the lake. However, they argued that increasing salinity can even cause extinction of $C$. torosa in Large Aral but the species present in Small Aral, implying that even C. torosa has some upper limits of salinity tolerance. During the present study, there are, however, variations of the species occurrence patterns among the stations. For example, one possible explanation of such occurrence may be considered that station 1 receives a water discharge from a small creek (Figure 1) but it is also faced with a seasonal sea water intrusion when sea water level rises over the narrow coastal barrier into the lake area (Dalkıran N., pers. comm). Thus, one may argue that this water back up from the creek may reduce salinity (also referring to electrical conductivity) at that sampling point lower than what $C$. torosa prefers although the species can tolerate wide ranges of salinity (and temperature) values. In a microcosm study, Frenzel et al. (2012) showed highest numbers of reproductive rates at the salinities ranged from 3 to 8 psu while noded valves being most abundant below 2 psu were also found up to $7 \mathrm{psu}$. The authors reported smooth valves above the limit $7 \mathrm{psu}$. Accordingly, their study showed similar trend for both males and females. In our case, however, salinity ranges between the station 1 ( 0.16 and 0.69 ppt) and the station 6 ( 0.21 and 0.47 ppt) overlap. Therefore, insignificant level of salinity range does not explain why $C$. torosa was relatively abundant in station 6 but station 1 .

Most recently, Pint and Frenzel (2017) proposed a flowchart for paleoenvironmental interpretation based on the species dominancy. Hence, if dominancy of the species is more than $90 \%$, the habitat can be characterized as hypersaline or with oxygen deficiency. In contrast, dominancy with less than $90 \%$ refers to fresh to brackish waters. Although their application is suggested to use fossil occurrences of the species, it seems that it can also be used to determine habitats with present conditions. We collected $C$. torosa from the stations (but cf. station 1) with more than $90 \%$ of dominancy almost all year round. This finding suggests that the delta is of hypersaline conditions, but this does not support oxygen deficiency due to a relatively high mean oxygen value (ca. $7.16 \mathrm{mg} / \mathrm{L})$

\section{Mg, Ca And Noding}

This explanation above may have a value since salinity, $\mathrm{Mg}$ and $\mathrm{Ca}$ measurements were significantly different between stations (1st and 6th ) and others $(2-5,7$ th $)$ where the species exhibited seasonal occurrence patterns with high abundance. No significant difference $(P>0.05)$ was found for other variables. Station 6 is located on the Çapraz River which flows continuously through Marmara Sea but intrusion from the sea occurs seasonally. Thus, its water is mixed all the time where both smooth and smooth-noded individuals were collected during the study. Both elements are necessary for the carapace formation while $\mathrm{Ca}$ is generally higher than $\mathrm{Mg}$ in the carapace. However, with a few exceptions, Mg values of the stations were found almost always much higher than Ca during the present study. These differences were apparent between two stations (1 and 6) which were the furthest in distance to the Marmara Sea. Indeed, we found $C$. torosa from the known ranges of these variables obtained in the literature. What is however imperative is to associate species frequent occurrences amid the stations with or without (or both) noded carapaces. As mentioned, carapace morphology seems to be related to salinity (and temperature) changes in waters that noded individuals tend to be found more commonly in freshwaters than brackish or saline waters. In addition to these variables, however, previous studies (Keyser 2005, Frenzel et al. 2012) pointed out that node formation might also be correlated to deficiency of Ca level, suggesting that numbers of nodes can be increased in the waters with low Ca. Although the correlation was medium and not significant (Table 3), our results support the opposite of this view that the mean Ca level (197.85 mg/L) was the lowest among other groups where there were only individuals with smooth carapaces (Table 2). While working on another species (Limnocythere inopinata) in Lake Van (Turkey) known with Ca limitation ( 0.105 to $0.087 \mathrm{mmol} / \mathrm{L}$ ) (Reimer et al 2009), similar finding was outlined by McCormack et al. (2019) that node formation may be influenced by several other factors that $\mathrm{Mg}$ may be one of them. Our values are clearly much higher than these values and apparently good enough to build carapace structure. However, again, this does not really explain absence (except one female) of $C$. torosa at station 1 although its chemical composition is similar to station 6 where the species was relatively higher in numbers and in their occurrences.

Several studies (Meisch 2000) showed that some species and/or genera can be associated to lower salinity ranges. For example, finding members of the genus Candona from station 1 may support this view due to their freshwater habitat preferences with low salinities (Neale 1988; Karanovic 2012) but we are still not able to answer why $C$. torosa was not found and/or was not common in there. This question is important because some taxa reported in here (e.g., Heterocypris salina, Eucypris sp., Plesiocypridopsis sp., Cypridopsis sp.) are already known to survive in wide ranges of salinity, temperature and/or $\mathrm{pH}$ values (Delorme 1991). As indicated in their excellent review, Dettman and Dwyer (2012) clearly underlined that there can be several other factors effective on carapace chemistry and structure. Hence, there is no single explanation about the relationships between the formation of nodes on the carapace and $\mathrm{Mg}, \mathrm{Ca}$ and/or $\mathrm{Mg} / \mathrm{Ca}$ in waters. On the other hand, Figure 3 suggests that it is electrical conductivity closely related to species occurrence/abundance more than $\mathrm{Mg}$ and $\mathrm{Ca}$ alone. Moreover, our results with $\mathrm{Mg}$ and node formation tend to support similar explanation used for $\mathrm{Ca}$ where individuals without nodes were solely found below the mean $(555 \mathrm{mg} / \mathrm{L})$ of $\mathrm{Mg}$ level. 


\section{Temperature, Seasonality And Noding}

Herman et al. (1983) showed that $C$. torosa has one generation that several factors can be effective on its life cycle and occurrences. For example, salinity increase can be directly intimated with temperature. This is actually the case for $C$. torosa. Heip (1976a, b), after more than four years of his continuous work, illustrated that abundance and occurrence of the adults were triggered and were closely related to water temperature above $15 \otimes C$. Our results are mostly supportive on this approach with a few exceptions in some months (see Table 1) where adults are high in numbers below this proposed temperature level. For example, in total, there were more adults at the station 3 during January and February 2019 where water temperature was 6.03 and $13.2 \llbracket \mathrm{C}$, respectively. In contrast, a medium correlation between water temperature and abundance of the species was not significant. Nevertheless, this does not change the general view proposed by Heip (1976a) that numbers of adults increase with increasing temperature (and salinity) but this should be investigated in detailed studies.

On the other hand, relating the temperature to monthly occurrences of the noding, it is apparently valuable to indicate that occurrence of adults without nodes are mostly beginning within the end of fall season (November) until spring season (April). Similarly, the individuals without nodes (but with a few exceptions) were reported all year around from a eutrophic lake, Lake Küçükçekmece (Turkey) (Külköylüoğlu et al. 1993). In another monthly study, however, Külköylüoğlu et al. (1995) reported a similar pattern of the noded and smooth individuals of $C$. torosa from a brackish water lake (Lake Büyükçekmece) (now the lake is of freshwater characteristics due to separation from the Marmara Sea in 1985) in summer (June) and winter (December) seasons. In both studies, authors failed to measure salinity values of the lakes but Külköylüoğlu et al. (1995) underlined that node formations might be a necessary issue for the species because it probably helps the species movement on the sediment in freshwater conditions while the species may not need the nodes in saline waters due to lifting force. These authors did not ask a specific question about the correlation between nodding and salinity in the study. Additionally, these explanations may not represent true nature of the correlation between node formations and water chemistry. However, they help to deduce an understanding of it. Nevertheless, as shown in previous studies (see above), node formations are possibly a response to environmental factors.

\section{Ph, Alkalinity And Noding}

Alkalinity was suggested as an effective factor on the carapace structure and formation of nodes (Van Harten 2000; McCormack et al 2019); for instance, De Deckker and Lord $(2017$, p.4) stated that "... It is unfortunate that neither Vesper nor Heip measured alkalinity of the waters during their long investigations of the life cycles of torosa, and this needs to be examined in the future so as to better understand ostracod shell composition. Alkalinity, combined with ionic analysis of the ambient waters will lead to identification of the calcite saturation nature of the waters in which ostracods moult and grow." We did not measure alkalinity during the present study, but pH values were measured. Moreover, we are aware of that pH and alkalinity of waters are not same, but they are closely related (Boyd et al 2017). Implication of this relationship is that increasing pH values (> 7, referring to alkaline or basic waters) means high alkalinity. In a very comprehensive work of Boyd et al. (2017), this relationship in waters is provided as: $\mathrm{pH}=6.6$, alkalinity $=1 \mathrm{mg} / \mathrm{L}$; $\mathrm{pH}=7.3$, alkalinity $=5 \mathrm{mg} / \mathrm{L} ; \mathrm{pH}=7.6$, alkalinity $=10 \mathrm{mg} / \mathrm{L} ; \mathrm{pH}=8.3$, alkalinity $=50 \mathrm{mg} / \mathrm{L}$. This information may be applied to the studies; for example, $C$. torosa was reported in the waters of Terschelling Island where $\mathrm{pH}$ values were measured between 7.5 and 8.5 (Scharf and Hollwedel 2010 ). Implication is that alkalinity was at least 10 or more in the waters of the island. During the present study, we have $77 \mathrm{pH}$ measurements. There are only 16 of 77 cases where $\mathrm{pH}$ values were below 8.0. Of which, there are only three cases $(\mathrm{pH}=7.84,7.92$, and 7.96) where we identified live $C$. torosa (first two with noded individuals and the last one with smooth individuals, respectively) while we found no ostracods or only valves/carapaces in six and seven cases (mostly smooth and noded-smooth individuals but no single population with solely noded individuals found), respectively. Rest of the cases (61 of 77 ) includes $\mathrm{pH}$ values $\geq 8$.0. Adapting the equations of Boyd et al. (2017), we may link the pH values (now referring to alkalinity values above) to the noding on carapaces. The mean $\mathrm{pH}$ values (8.14-8.47) among the stations did not show significant difference but it can be inferred that the species may prefer waters with alkalinities above $10 \mathrm{mg} / \mathrm{L}$ or even $50 \mathrm{mg} / \mathrm{L}$. This can be useful information provided in here for the first time that such a view may be used in fossil forms for understanding past environmental conditions in paleontological studies.

\section{Fossil Vs Recent (Live) Forms}

In Turkey, C. torosa was reported from Early Miocene (Ilgar and Nemec 2005) corresponding to the previous records (cf. Van Harten 2000; Witt 2010; Wouters 2017). When we compare dispersion of the fossil and live species reported so far (Figure 2), numbers of fossil records from about 24 provinces (aka cities) are higher than living specimens in 20 provinces. With a few exceptions (Figure 2), living forms have been mostly coupled with fossil records reported from nearby the coastal zones of west and northwest (around Marmara Sea) of Turkey. Although there are extensive studies in some provinces (e.g., Sinop, Çankırı, Eshişehir, Elazığ, Konya), which includes about 1000 water samples, there are only surface sediemeant samples of (sub/fossils) $C$. torosa populations reported from them. Last four of these cities (and more others, see the Figure 2) are far away from the seas and are located within Anatolia where fossils were found in several different water bodies. Two other similar proxies can be worth to discuss: First, $C$. torosa with smooth and noded individuals were reported from Holocene samples of the Lake Sevan (Armenia) (Wilkinson et al 2005). The lake is located at 1900 $\mathrm{m}$ asl and has no connection to seas. The authors pinpointed those smooth forms were encountered in a Holocene sequence more than noded forms, implying that the lake salinity had been increased during at least the last 5000 years or late Holocene. Second, similarly, in Germany, Scharf et al. (2017) reported Quaternary fossils of $C$. torosa from 32 of 45 inland sites far away (more than $200 \mathrm{~km}$ ) from the Baltic and the North seas. Opposite situation is also true for live populations with a few cases. There can be at least three possible ways to delineate this situation (1) lack of studies, (2) unsuitable habitats for 
the species, and (3) no time for the species migration yet. On the other hands, we believe that such a map showing overlapping ranges of both fossil and live forms can help us to understand species distribution since the Early Miocene in Turkey.

Overall, in conclusion, as stated above, alkalinity was not directly measured in situ, we cannot provide a good explanation for its correlation with noding of the carapace. However, we agree that a combination of salinity and/or alkalinity with other environmental variables and biotic variables may be a better way to apply in future studies. Indeed, total nitrogen (and phosphorous) portrayed medium correlation $(P>0.05)$ to the species abundance among the stations. Consulting Figure 1 and site description above, one can recognize agricultural activities or so called "human activities" around the study area. According to Chen et al. (2015), global distribution of TN and TP values in lakes can be found between $0.526 \mathrm{mg} / \mathrm{L}$ and $0.014 \mathrm{mg} / \mathrm{L}$. Our mean values are all higher than these values (cf. Table 2). This implies possible sources of nitrogen and phosphate and their compounds reaching to the sampling sites due to human activities. It appears that $C$. torosa can even overcome all these artificial inputs due to its high tolerance ranges. As indicated by Frenzel et al. (2012), C. torosa can be used as a good indicator species because of the populations inhabiting or preferring a wide range of salinities. For example, individuals of the athalassic populations from stable water bodies can be used to describe continuous and detailed water bodies. Although this finding is of a scientific merit, we cannot make detailed discussion in here about these compounds due to lack of studies.

\section{Statements And Declarations}

The authors declare that no funds, grants, or other support were received during the

preparation of this manuscript.

\section{Acknowledgements}

Prof. Dr. Dietmer Keyser (Zoologisches Institut Universität Hamburg, Germany) and Dr. Alaettin Tuncer (Hacettepe University, Turkey) are thanked for personal communication. This study was part of a project (No: DDP(F)-2018/13) supported by Bursa Uludağ University.

\section{Conflict of interest}

The authors have no relevant financial or non-financial interests to disclose.

\section{Author Contributions}

All authors contributed to the study conception and design. Material preparation, data collection were performed by Enis Akay and Nurhayat Dalkıran. Ostracod samples preparation and analyses were provided by Okan Külköylüoğlu and Mehmet Yavuzatmaca. The first draft of the manuscript was written by Okan Külköylüoğlu and all authors commented on previous versions of the manuscript. All authors read and approved the final manuscript.

\section{Data availability}

The datasets generated during and/or analysed during the current study are available from the corresponding author on reasonable request.

\section{References}

1. Akdemir D, Külköylüoğlu O (2021) Effects of temperature changes on the spatial distribution and ecology of ostracod (Crustacea) species. J Limnol Freshw Fisheries Res 7(1):1-13. doi: 10.17216/LimnoFish.765049

2. Akdemir D, Külköylüoğlu O, Yavuzatmaca M et al (2020) Ecological characteristics and habitat preferences of Ostracoda (Crustacea) with a new bisexual population record (Muğla. Turkey). Appl Ecol Environ Res 18(1):1471-1487. doi: 10.15666/aeer/1801_14711487

3. Aladin NV (1993) Salinity tolerance morphology and physiology of the osmoregulation organs in Ostracoda with special reference to Ostracoda from the Aral Sea. In: Jones P, McKenzie K (eds) Ostracoda in the Earth and Life Sciences. AA Balkema, Rotterdam, pp 387-404

4. APHA (1998) Standard methods for the examination of water and wastewater, 20th edn. American Public Health Association, American Water Works Association, Water Environment Federation, Washington D.C.

5. Berndt C, Frenzel F, Çiner A (2019) Intraspecifc length Variation and shell thickness of the ostracod Cyprideis torosa (Jones. 1850) as a potential tool for palaeosalinity characterization. Geosci 9(83):1-13. doi: 10.3390/Geosci9020083

6. Bodergat AM, Lécuyer C, Martineau F et al (2014) Oxygen isotope variability in calcite shells of the ostracod Cyprideis torosa in Akyatan Lagoon, Turkey. J Paleolimnol 52:43-59. doi: 10.1007/s10933-014-9777-3

7. Boyd CE, Tucker CS, Somridhivej B (2017) Alkalinity and hardness: Critical but elusive concepts in aquaculture. J World Aquac Soc 47(1):6-41. doi: $10.1111 /$ jwas. 12241

8. Bronshtein ZS (1947) Freshwater Ostracoda. Fauna of the USSR Crustacea V:2. No.1. Russian Translation Series. 64. Academy of Sciences of the USSR Publishers. Moscow. 1988. p. 470

9. Chen M, Zeng G, Zhang J et al (2015) Global landscape of total organic carbon, nitrogen and phosphorus in lake water. Sci Rep 5:15043. doi.org/10.1038/srep15043

10. De Deckker P, Lord A (2017) Cyprideis torosa: a model organism for the Ostracoda? J Micropalaeontology 36:3-6. doi: 10.1144/jmpaleo2016-100 
11. Delorme LD (1991) Ostracoda. In: Thorpe JH, Covich AP (eds) Ecology and classification of North American invertebrates. Academic Press, New York, pp 691-722

12. Detmann DL, Dwyer GS (2012) The calibration of environmental controls on elemental ratios in ostracod shell calcite: A critical assessment. In: Horne D, Holmes JA, (eds) Ostracoda as proxies for Quaternary climate change 17: 15-164

13. Dykan N (2016) Neogene-Quaternary Ostracodes of the Northern Part of the Black Sea; Publishing House "Chetverta Hvylja”: Kiev. Ukraine. p. 272

14. Elofson OMG (1941) Zur Kenntnis der marinen Ostracoden Schwedens mit besonderer Berücksichtigung des Skageraks. Zool Bidrag 19:215-534

15. Frenzel P, Schulze I, Pint A (2012) Noding of Cyprideis torosa valves (Ostracoda)-a proxy for salinity? New data from field observations and a long term microcosm experiment. Int Rev Hydrobiol 97:314-329. doi: 10.1002/iroh.201211494

16. Frogley MR, Whittaker JE (2016) On the origins of Cyprideis torosa (Jones. 1850) and a short biography of Professor T.R. Jones. J Micropalaeontology 36(1):8. doi: 10.1144/jmpaleo2015-023

17. Gülen D (1985) Bisexual Ostracoda (Crustacea) populations in Anatolia. İstanbul Universitesi Fen Fakültesi Mecmuası (Seri B) 50:81-86

18. Hammer $\varnothing$, Harper DAT, Ryan PD (2001) PAST: Paleontological statistics software package for education and data analysis. Palaeontol Electronica $4(1): 9$

19. Hartmann G (1964) Das Problem der Buckelbildung auf Schalen von Ostracoden in ökologischer und historischer Sicht (Mit Bemerkungen zur Fauna des Trasimenischen Sees). Mitteilungen aus dem Hamburgischen Zoologischen Museum und Institut (Kosswig-Festschrift): 61 (Supplementary): 59 60

20. Heip C (1976a) The life-cycle of Cyprideis torosa (Crustacea, Ostracoda). Oecologia 24:229-245. doi: 10.1007/bf00345475

21. Heip C (1976b) The spatial pattern of Cyprideis torosa (Jones, 1850) (Crustacea: Ostracoda). J Mar Biolog Assoc 56:179-189. doi: $10.1017 / \mathrm{s} 002531540002052 x$

22. Herman PMJ, Heip C, Vranken G (1983) The production of Cyprideis torosa Jones 1850 (Crustacea. Ostracoda). Oecologia 58:326-331. doi: $10.1007 / \mathrm{bf} 00385231$

23. Ilgar A, Nemec W (2005) Early Miocene lacustrine deposits and sequence stratigraphy of the Ermenek Basin. Central Taurides Turkey Sediment Geol 173(1):233-275. doi: 10.1016/j.sedgeo.2003.07.007

24. Jahn A, Gamenick I, Theede H (1996) Physiological adaptations of Cyprideis torosa (Crustacea, Ostracoda) to hydrogen sulphide. Marine Ecology Progress Series 142: 215-223.Karanovic I (2012). Recent Freshwater Ostracods of the World: Crustacea, Ostracoda, Podocopida. Springer Science \& Business Media: The Hague. The Netherlands

25. Keçeli T, Ursavaş S (2019) Contributions to the Liverwort and Hornwort (Marchantiophyta and Anthocerotophyta) Flora of Kocaçay Delta (KaracabeyBursa) Floodplain Forest. Anatol Bryol 5(1):45-55 doi: 10.26672/anatolianbryology.528831

26. Keyser D (2005) Histological peculiarities of the noding process in Cyprideis torosa (Jones) (Crustacea. Ostracoda). Hydrobiologia 538:95-106. doi: $10.1007 /$ s10750-004-4940-x

27. Keyser D, Aladin N (2004) Noding in Cyprideis torosa and its causes. Stud Quat 21:19-24

28. Kilenyi TI (1972) Transient and balanced genetic polymorphism as an explanation of variable noding in the ostracode Cyprideis torosa. Micropaleontology 18: 47-63. doi: 10.2307/1484978. 1972

29. Klie W (1938) Ostracoda. Muschelkrebse. Die Tierwelt Deutschlands und der angrenzenden Meeresteile nach ihren Merkmalen und nach ihrer Lebensweise. 34. Teil: Krebstiere oder Crustacea. Gustav Fischer, Jena, pp 1-230

30. Külköylüoğlu O, Altınsaçlı S, Kubanç C (1993) The Ostracoda (Crustacea) fauna of Küçükçekmece Lake (İstanbul) and seasonal distributions. Turk J Zool 17(1):19-27

31. Külköylüoğlu O, Altınsaçlı S, Kılıç M, Kubanç C (1995) The Ostracoda (Crustacea) fauna of Lake Büyükçekmece (İstanbul) and seasonal distributions. Turk J Zool 19(3):249-256

32. Külköylüoğlu O, Yavuzatmaca M, Yılmaz O (2020) Ecology and distribution of ostracods in Mardin and Muş provinces in Turkey. Biologia 75:18551870 doi: $10.2478 /$ s11756-020-00439-5

33. Külköylüoğlu O, Hutchins BT, Yavuzatmaca M, Schwartz BF (2021a) Hyporheic ostracods (Crustacea. Ostracoda) from Texas (USA) with six new species. Zootaxa 5046(1):1-63. doi.org/10.11646/zootaxa.5046.1.1

34. Külköylüoğlu O, Yavuzatmaca M, Akdemir D (2021b) Occurrence patterns, photoperiod and dispersion ability of the non-marine Ostracoda (Crustacea) in shallow waters. Turkish J Fish Aquat Sci 21(2):73-85. doi: 10.4194/1303-2712-v21_2_03

35. McCormack J, Viehberg F, Akdemir D et al (2019) Ostracods as ecological and isotopic indicators of lake water salinity changes: the Lake Van example. BioGeosci 16:2095-2114. doi: 10.5194/bg-16-2095-2019

36. Meisch C (2000) Freshwater Ostracoda of Western and Central Europe (Süsswasserfauna von Mitteleuropa). I-xii, vol 8. Spektrum Akademischer Verlag, Heidelberg, p 522

37. Meisch C, Smith RJ, Martens K (2019) A subjective global checklist of the extant non-marine Ostracoda (Crustacea). Eur J Taxon 492:1-135. doi: 10.5852/ejt.2019.492

38. Nazik A, Türkmen I, Koç C, Aksoy E, Avşar N, Yayık H (2008) Fresh and brackish water ostracods of Upper Miocene deposits. Arguvan/Malatya (Eastern Anatolia). Turkish J Earth Sci 17(3):481-495 
39. Neale JW (1988) Ostracods and palaeosalinity reconstruction. In: De Deckker P, Colin JP, Peypouquet JP (eds) Ostracoda in earth sciences. Elsevier, Amsterdam, pp 125-155

40. Pint A, Frenzel P (2017) Ostracod fauna associated with Cyprideis torosa - an overview. J Micropalaeontology 36:113-119. doi: 10.1144/jmpaleo2016-010

41. Plotnikov IS, Aladin NV, Mossin J, Høeg JT (2021) Crustacean fauna of the Aral Sea and its relation to ichthyofauna during the modern regression crisis and efforts at restoration. Zool Stud 60:25. doi:10.6620/ZS.2021.60-25

42. Reimer A, Landmann G, Kempe S (2009) Lake Van, Eastern Anatolia, hydrochemistry and history. Aquat Geochem 15:195-222. doi: 10.1007/s10498008-9049-9

43. Rosenfeld A, Vesper B (1977) The variability of the sieve-pores in recent and fossil species of Cyprideis torosa (Jones. 1850) as an indicator for salinity and palaeosalinity. In: Löffler H, Danieolopol D, (eds) Aspects of ecology and zoogeography of recent and fossil Ostracoda: proceedings of the 6th International Symposium on Ostracods. Saalfelden (Salzburg), July 30 - August 8, 1976

44. Sandberg P (1964) The ostracod genus Cyprideis in the Americas. Stockholm Contrib Geol 12:1-178

45. Sars GO (1928) An account of the Crustacea of Norway. The Bergen Museum, Oslo, Norway 9: 1-277

46. Scharf B, Herzog M, Pint A (2017) New occurrences of Cyprideis torosa (Crustacea. Ostracoda) in Germany. J Micropalaeontology 36:120-126 doi: 10.1144/jmpaleo2015-022

47. Scharf B, Hollwedel W (2010) Ostracoda und Cladocera (Crustacea) von der Insel Terschelling. Niederlande. Drosera 2009: 127-141

48. Schornikov El (2011) Problems of studying Ostracoda from The Caspian Basin. Joannea Geol Palaontol 11:177-179

49. Triebel E (1941) Zur Morphologie und Ökologie der fossilen Ostracoden mit Beschreibung einiger neuer Gattungen und Arten. Senckenbergiana 23:294-400

50. Ustaoğlu MR, Özdemir Mis D, Aygen C (2012) Observations on zooplankton in some lagoons in Turkey. J Black Sea/Mediterr Environ 18(2):208-222

51. Van Harten D (1975) Size and environmental salinity in the euryhaline ostracod Cyprideis torosa (Jones. 1850), a biometrical study. Palaeogeogr Palaeoclimatol Palaeoecol 17:35-48. doi: 10.1016/0031-0182(75)90028-0

52. Van Harten D (2000) Variable noding in Cyprideis torosa (Ostracoda. Crustacea): an overview. experimental results and a model from Catastrophe Theory. Hydrobiologia 419:131-139. doi: 10.1023/A:1003935419364

53. Van Morkhoven FPCM (1962) Post-Palaeozoic Ostracoda. Their morphology, taxonomy and economic use. Q Rev Biol 40(2):189-190

54. Vesper B (1972a) Zur Morphologie und ökologie von Cyprideis torosa (Jones 1850) (Crustacea. Ostracoda. Cytheridae) unter besonderer Berücksichtigung seiner Biometrie. Mitteilungen aus dem Hamburgischen Zoologischen Museum und Institut 68:21-77

55. Vesper B (1972b) Zum Problem der Buckelbildung bei Cyprideis torosa (Jones. 1850) (Crustacea. Ostracoda. Cytheridae). Mitteilungen aus dem Hamburgischen Zoologischen Museum und Institut 68: 79-94

56. Wilkinson IP, Bubikyan SA, Gulakyan SZ (2005) The impact of late Holocene environmental change on lacustrine Osracoda in Armenia. Palaeogeogr Palaeoclimatol Palaeoecol 225:187-202. doi: 10.1016/j.palaeo.2005.06.010

57. Witt W (2010) Late Miocene non-marine ostracods from the Lake Küçükçekmece region, Thrace (Turkey). Zitteliana 50(143):89-101

58. Wouters K (2002) On the distribution of Cyprideis torosa (Jones) (Crustacea. Ostracoda) in Africa. with the discussion of a new record from the Seychelles. Bulletin de L'Institut Royal des Sciences Naturelles de Belgique, Biologie 72: 131-140

59. Wouters K (2003) New records of the genus Cyprideis (Crustacea. Ostracoda) from South Africa. Bulletin de L'Institut Royal des Sciences Naturelles de Belgique, Biologie 73: 161-165

60. Wouters K (2017) On the modern distribution of the euryhaline species Cyprideis torosa (Jones. 1850) (Crustacea. Ostracoda). J Micropalaeontology 36:21-30. doi: 10.1144/jmpaleo2015-021

\section{Figures}




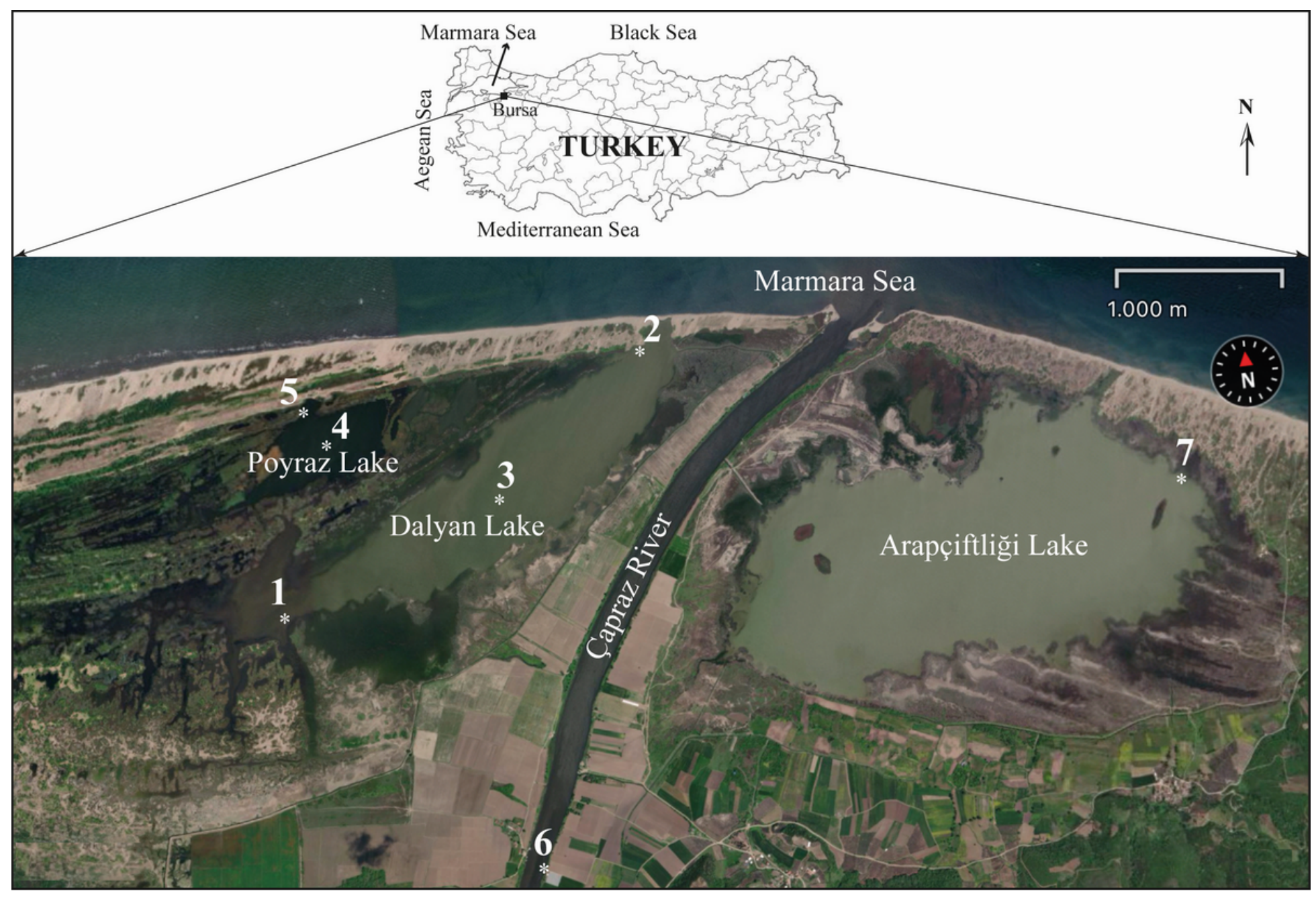

Figure 1

The seven sampling stations in Kocaçay Delta (Bursa, Turkey). 


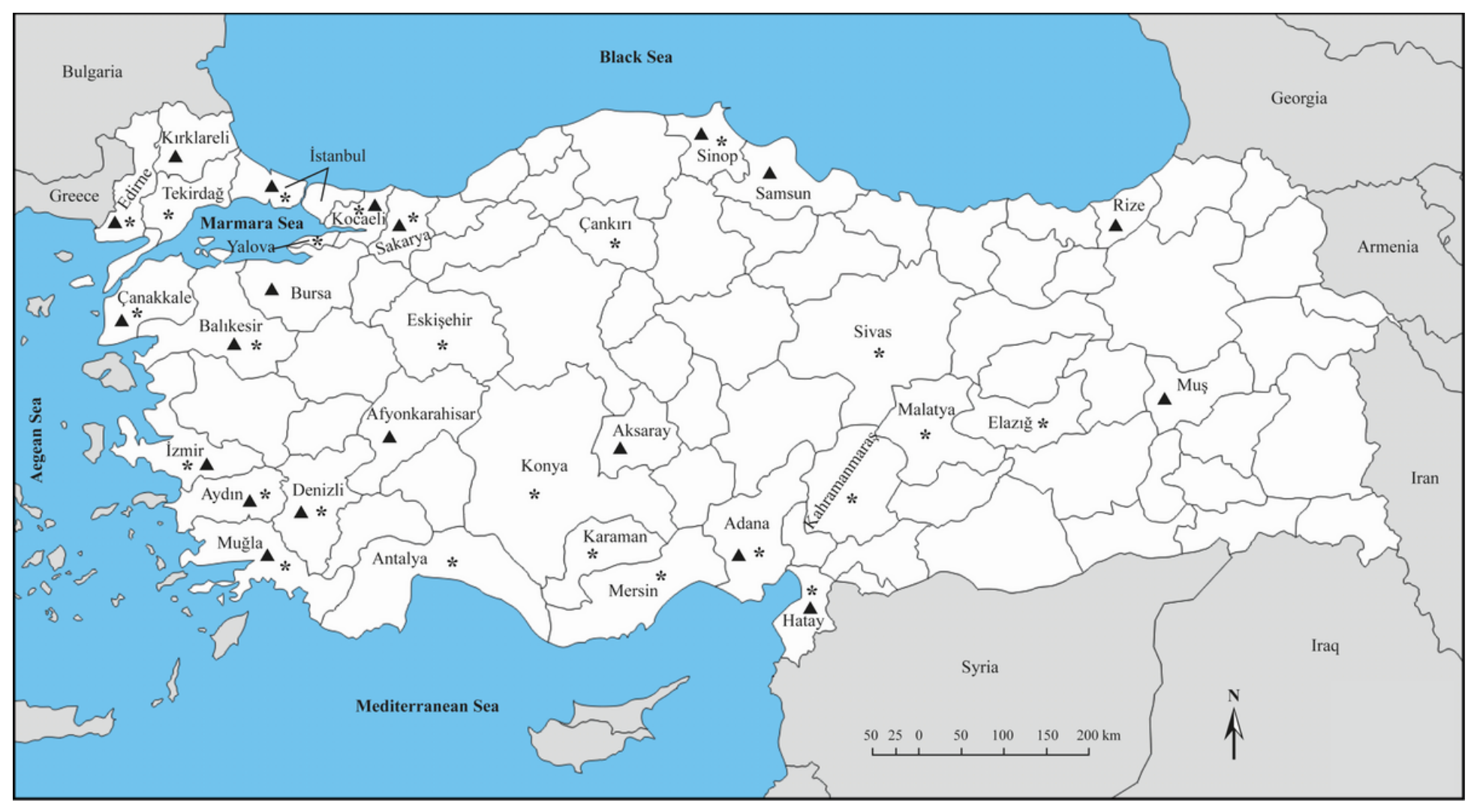

Figure 2

Distribution of fossil $\left(^{*}\right)$ and recent $(\boldsymbol{\Delta})$ Cyprideis torosa in Turkey (see Appendix for the references). 

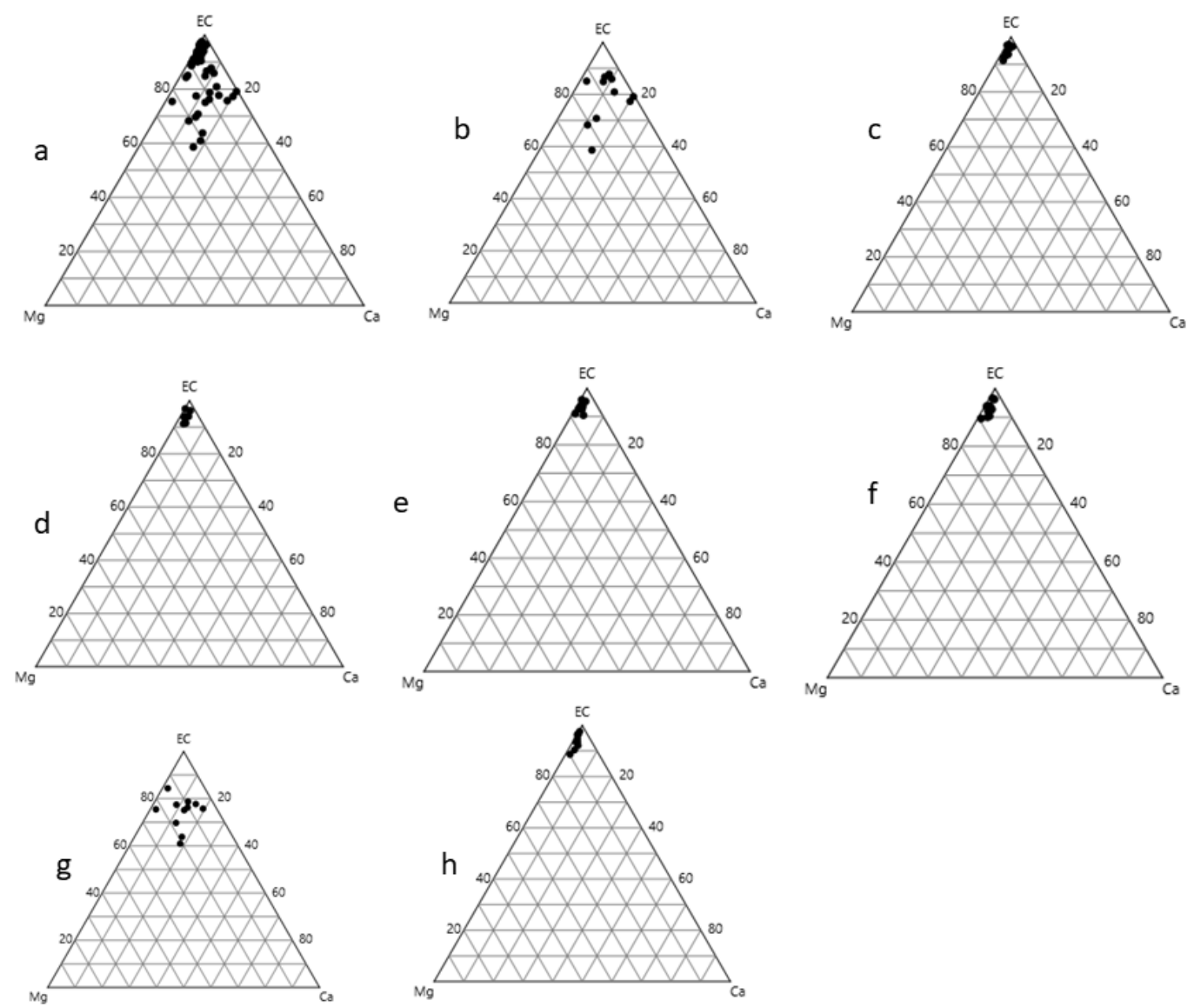

Figure 3

Ternary plots with percentage values show relationtionships among $\mathrm{Ca}, \mathrm{Mg}$ and EC for all data (a) and stations 1-7 (b-h).

\section{Supplementary Files}

This is a list of supplementary files associated with this preprint. Click to download.

- Appendix.docx 